\title{
Amyloid-Degrading Ability of Nattokinase from Bacillus subtilis Natto
}

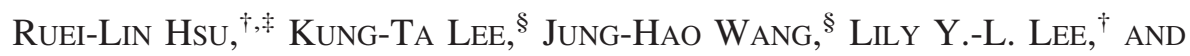 \\ RITA P.-Y. CHEN ${ }^{*},+\neq$ \\ Institute of Biological Chemistry, Academia Sinica, Taipei 115, Taiwan, R. O. C., Institute of \\ Biochemical Sciences, National Taiwan University, Taipei 106, Taiwan, R. O. C., and Department of \\ Biochemical Science and Technology, National Taiwan University, Taipei 106, Taiwan, R. O. C.
}

\begin{abstract}
More than 20 unrelated proteins can form amyloid fibrils in vivo which are related to various diseases, such as Alzheimer's disease, prion disease, and systematic amyloidosis. Amyloid fibrils are an ordered protein aggregate with a lamellar cross- $\beta$ structure. Enhancing amyloid clearance is one of the targets of the therapy of these amyloid-related diseases. Although there is debate on whether the toxicity is due to amyloids or their precursors, research on the degradation of amyloids may help prevent or alleviate these diseases. In this study, we explored the amyloid-degrading ability of nattokinase, a fibrinolytic subtilisin-like serine protease, and determined the optimal conditions for amyloid hydrolysis. This ability is shared by proteinase $\mathrm{K}$ and subtilisin Carlsberg, but not by trypsin or plasmin.
\end{abstract}

KEYWORDS: Nattokinase; amyloid; natto; subtilisin NAT; amyloid degradation; fibril; amyloidosis

\section{INTRODUCTION}

Natto, a fermented food made from boiled soybeans, has been eaten for more than 1000 years in Asia. The fermentation microbe isolated from natto is the Gram-positive endospore-forming bacterium Bacillus subtilis natto (formerly designated Bacillus natto) (1). Nattokinase (formerly designated Subtilisin NAT) (2) is an extracellular enzyme secreted by $B$. subtilis natto (3) and belongs to the alkaline serine protease family, the catalytic center of which contains three conserved residues, Asp-32, His-64, and Ser-221 (4). It has a molecular mass of $27.7 \mathrm{kDa}$ and an isoelectric point of 8.7 (5). Nattokinase is composed of 275 amino acids, and the gene sequence is homologous to those of other members of the subtilisin family $(99.5 \%$ homology with subtilisin E, $86 \%$ with subtilisin $\mathrm{BPN}^{\prime}$, and $72 \%$ with subtilisin Carlsberg) (6). It not only degrades fibrin in thrombi (7) but also cleaves plasminogen activator inhibitor type I $(7,8)$. Nattokinase has greater thrombolytic activity than plasmin $(5,7,9)$, a natural thrombolytic protease in blood, and increases the production of plasmin from plasminogen due to its action on plasminogen activator. These observations, together with the fact that it can be absorbed across the intestinal tract after oral administration $(10,11)$ and induce fibrinolysis $(11)$, make nattokinase a potential clot-dissolving agent for the treatment

* Author to whom correspondence should be addressed: Rita P.-Y. Chen, Institute of Biological Chemistry, Academia Sinica, No 128, Sec 2, Academia Rd, Nankang, Taipei, 115, Taiwan. Tel: +886-2-27855696. Fax: +886-2-2788-9759. E-mail: pyc@gate.sinica.edu.tw.

${ }^{\dagger}$ Academia Sinica.

* Institute of Biochemical Sciences, National Taiwan University.

$\S$ Department of Biochemical Science and Technology, National Taiwan University. of cardiovascular disease. Dietary supplementation with natto suppresses the intimal thickening of arteries and leads to the lysis of mural thrombi seen after endothelial injury (12). Other clinically thrombolytic agents, such as urokinase and streptokinase, are costly and unstable in the intestinal tract (13). The use of oral administration of nattokinase in fibrinolytic therapy for thrombosis and the prevention of atherosclerosis is therefore of interest. Nattokinase is currently used as a nutrient supplement to improve circulation in the body $(3,11,12)$.

Although much research has been carried out on nattokinase, there has been no interest in whether it can degrade amyloids, which are also highly insoluble and proteaseresistant. Here, we tested its ability to degrade amyloid fibrils formed from three different proteins and peptides. The first sample was $\mathrm{A} \beta 40$ fibrils; amyloid plaque formation is one of the pathological characteristics of Alzheimer's disease, and $\mathrm{A} \beta 40$ is one of the major cleaved products of human amyloid precursor protein and the major component of amyloid plaques. The second sample was insulin fibrils, as repeated insulin injection of diabetes patients can cause injection-localized amyloidosis (14). The third sample was prion peptide fibrils, as prion is the agent responsible for prion diseases. We synthesized the prion peptide corresponding to human prion sequence $(108-144)$ to produce amyloid fibrils, as previous observations have shown that it is the most likely segment to form an amyloid structure $(15,16)$. Human prion protein has either a Met or Val at position 129; we choose the Val-containing sequence, as the resulting amyloid fibrils gave a stronger fluorescence signal with the test agent, thioflavin $\mathrm{T}$ (ThT). 


\section{KDa Marker Nattokinase}

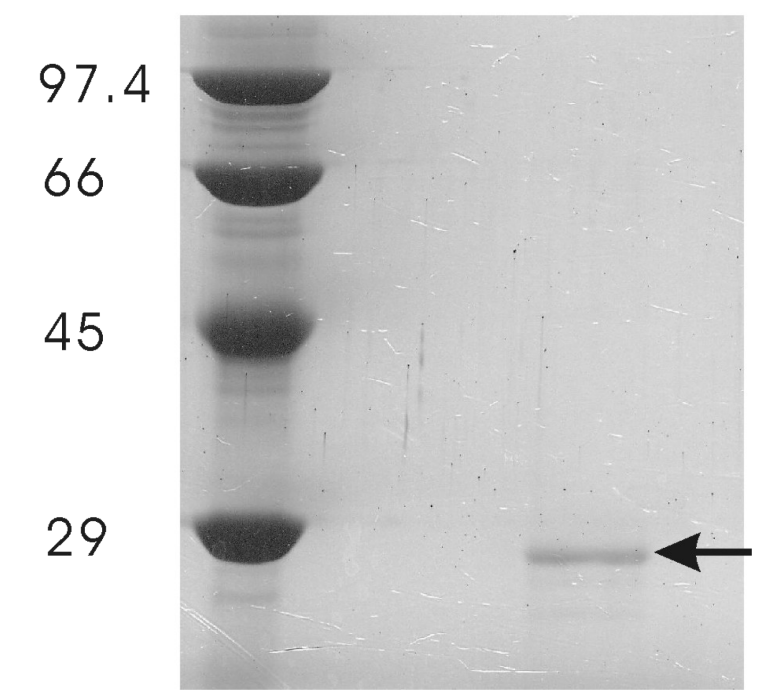

Figure 1. $15 \%$ SDS-PAGE of the purified nattokinase, indicated by the arrow.

\section{MATERIALS AND METHODS}

Production and Purification of Nattokinase. Bacillus subtilis natto was isolated from the commercial product and maintained on an $\mathrm{NB}$ slant at $4{ }^{\circ} \mathrm{C}$ (17). Production of nattokinase was performed in a 7-L fermentor (Bioflo 110 Modular Benchtop Fermentor, New Brunswick Scientific, NJ) based on the method described in our previous report (18). The working volume was $5 \mathrm{~L}$ of $5 \%(\mathrm{w} / \mathrm{v})$ soymilk ( $250 \mathrm{~g}$ of soybean powder in $5 \mathrm{~L}$ of $\mathrm{H}_{2} \mathrm{O}$ ), the aeration rate 1.0 volume per volume per minute, the agitation speed $800 \mathrm{rpm}$, and fermentation was performed at $37{ }^{\circ} \mathrm{C}$. All subsequent steps were at $4{ }^{\circ} \mathrm{C}$. After $28 \mathrm{~h}$, the supernatant was recovered by centrifugation at $12000 \mathrm{~g}$ and concentrated on an Amicon Ultra membrane with a $10 \mathrm{kDa}$ cutoff. The concentrated enzyme solution was applied to a gel filtration column $(2.6 \times 60 \mathrm{~cm})$ packed with $320 \mathrm{~mL}$ of HiPrep 26/60 Sephacryl S-100 high resolution gel (Amersham Biosci.) with a mobile phase of $50 \mathrm{mM}$ sodium phosphate and $150 \mathrm{mM}$ $\mathrm{NaCl}, \mathrm{pH} 7.0$, and a flow rate of $0.5 \mathrm{~mL} / \mathrm{min}$. One milliliter fractions were collected, and those with nattokinase activity and showing a single band on $15 \%$ SDS-PAGE were pooled. Nattokinase activity was determined by a chromogenic method using S2251 (H-D-Val-Leu-Lys-pNA; Sigma) as the substrate (19).

Peptide Synthesis. Peptide A $\beta 40$ (DAEFRHDSGYEVHHQKLVFFAEDVGSNKGAIIGLMVGGVV) and human prion peptide sequence 108-144 with Val at residue 129 (abbreviated as huPrP) (Ac-NMKHMAGAAAAGAVVGGLGGYVLGSAMSRPIIHFGSD-NH $\mathrm{N}_{2}$ ) were synthesized by the Fmoc-polyamide method on a PS3 peptide synthesizer (Rainin). The N-terminal end of the huPrP peptide was acetylated and the C-terminal end amidated in order to mimic the configuration in the full-length protein. Preloaded Fmoc-Val-Wang resin (substitution 0.47 $\mathrm{mmol} / \mathrm{g}$ ) was purchased from Anaspec Inc. and used in the synthesis of $\mathrm{A} \beta 40$, while Rink Amide AM resin (substitution $0.74 \mathrm{mmol} / \mathrm{g}$ ) was purchased from Novabiochem and used in the synthesis of huPrP. Fmoc-amino-acid derivatives $(0.4 \mathrm{mmol})$ were coupled to $0.1 \mathrm{mmol}$ of resin using $0.4 \mathrm{mmol}$ of benzotriazole-1-yl-oxy-tris-pyrrolidino-phosphonium hexafluorophosphate in dimethylformamide (DMF) containing $4.45 \%$ (v/v) of $N$-methylmorpholine. Acetylation of the N-terminal of huPrP was performed using $0.4 \mathrm{mmol}$ of acetic anhydride instead of amino-acid derivative in the synthetic procedure. Fmoc cleavage was performed using $20 \%$ (v/v) piperidine in DMF. The peptides were cleaved from the resin by stirring at room temperature for $1-2 \mathrm{~h}$ with a mixture of $9.4 \mathrm{~mL}$ of trifluoroacetic acid, $0.1 \mathrm{~mL}$ of triisopropylsilane, $0.25 \mathrm{~mL}$ of water, and $0.25 \mathrm{~mL}$ of ethanedithiol and precipitated with three volumes of ice-cold methyl $t$-butyl ether by centrifugation at $2000 \mathrm{~g}$ for $10 \mathrm{~min}$ at $4{ }^{\circ} \mathrm{C}$, then the pellet was washed another two times with methyl $t$-butyl ether and dried under vacuum. The resulting white powder was purified by reverse-phase HPLC using a Vydac C18 column $(10 \mathrm{~mm} \times 250 \mathrm{~mm})$ and acetonitrile-water mixtures containing $0.1 \%$ trifluoroacetic acid $(\mathrm{v} / \mathrm{v})$. The final products were analyzed by matrix-assisted laser desorption ionization (MALDI) mass spectrometer. Fractions containing the desired product were lyophilized and stored at $-20{ }^{\circ} \mathrm{C}$.

Preparation of Amyloid Fibrils. For A $\beta 40$ fibril formation, a $500 \mu \mathrm{M} \mathrm{A} \beta 40$ stock solution was prepared in $75 \%$ trifluoroethanol. The peptide concentration was quantified by the absorbance at $275 \mathrm{~nm}$. To form fibrils, the stock solution was diluted to $25 \mu \mathrm{M}$ in $20 \mathrm{mM}$ sodium phosphate buffer, $150 \mathrm{mM}$ $\mathrm{KCl}, \mathrm{pH} 7$, and incubated at $25^{\circ} \mathrm{C}$ for about two weeks $(20)$. The huPrP fibrils were prepared by dissolving the huPrP peptide in $20 \mathrm{mM} \mathrm{NaOAc}, 140 \mathrm{mM} \mathrm{NaCl}$, pH 3.7 to a final concentration of $50 \mu \mathrm{M}$ and incubating the solution at $25{ }^{\circ} \mathrm{C}$ for about one week $(15,16)$. To obtain insulin fibrils, bovine insulin (Sigma) was dissolved in dilute $\mathrm{HCl}(\mathrm{pH} 2.1)$ at a concentration of $2.5 \mathrm{mg} / \mathrm{mL}$ and incubated at $60^{\circ} \mathrm{C}$ for about two days $(21,22)$. Fibril formation was monitored by the appearance of negative ellipticity at $218 \mathrm{~nm}$ using circular dichroism spectroscopy or fluorescence emission on binding ThT using fluorescence spectroscopy.

Circular Dichroism (CD) Spectroscopy. The sample was placed in a $1-\mathrm{mm}$ quartz cell and the $\mathrm{CD}$ spectrum between 200 and $250 \mathrm{~nm}$ recorded on a J-715 CD spectrometer (JASCO, Japan). The bandwidth was set to $2 \mathrm{~nm}$ and the step resolution was $0.1 \mathrm{~nm}$. Two scans were averaged for each sample.

Thioflavin T Binding Assay. ThT binding assay measures the fluorescence intensity change in ThT on binding to amyloid fibrils. This method has been extensively used for identifying the presence of amyloid fibrils. A stock solution of $5 \mathrm{mM}$ ThT (Sigma) was prepared by dissolving $2 \mathrm{mg}$ of the dye in 1.25 $\mathrm{mL}$ of $140 \mathrm{mM} \mathrm{NaCl}, 100 \mathrm{mM}$ phosphate buffer, $\mathrm{pH} 8.5$, and passing the solution through a $0.22 \mu \mathrm{m}$ Millipore filter. A fresh working solution was prepared by adjusting the final dye concentration to $200 \mu \mathrm{M}$. A $30 \mu \mathrm{L}$ aliquot of the sample was mixed with $30 \mu \mathrm{L}$ of $200 \mu \mathrm{M}$ ThT dye solution for 1 min at room temperature, then the fluorescence emission between 460 and $600 \mathrm{~nm}$ was measured in a 3-mm path-length rectangular cuvette on a FP-750 spectrofluorometer (JASCO, Japan) with excitation at $442 \mathrm{~nm}$.

Protease Solutions. Stock solutions of all proteases (all except nattokinase from Sigma) used in this study were prepared at a concentration of $49 \mu \mathrm{M}$ and quantified by the Bradford assay (Bio-Rad). The protease solutions were prepared in different buffers according to the manufacturer's instructions; nattokinase and subtilisin Carlsberg were dissolved in $50 \mathrm{mM}$ phosphate buffer containing $150 \mathrm{mM} \mathrm{NaCl}, \mathrm{pH} 7$, proteinase $\mathrm{K}$ was dissolved in $10 \mathrm{mM}$ Tris- $\mathrm{HCl}$ buffer, $\mathrm{pH} 7$, trypsin was dissolved in $1 \mathrm{mM} \mathrm{HCl}$, and human plasmin was dissolved in distilled water.

Degradation of Different Kinds of Amyloid Fibrils by Nattokinase. The prepared $\mathrm{A} \beta 40$, huPrP, and insulin fibrils were collected by centrifugation at $14000 \mathrm{~g}$ for $20 \mathrm{~min}$ at room 
A

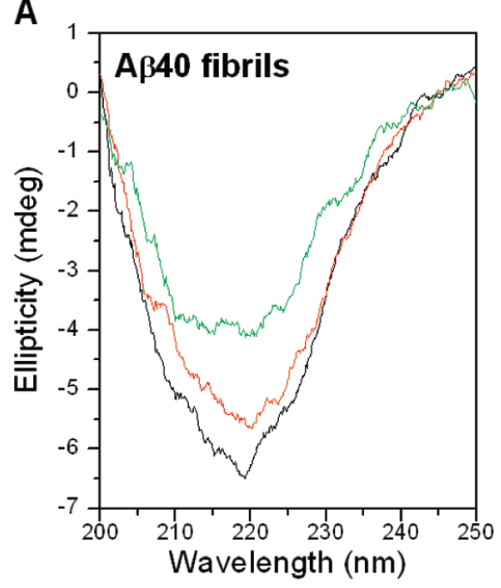

B

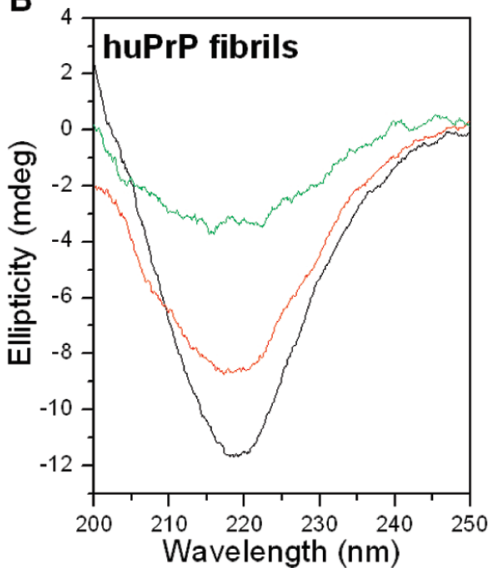

C

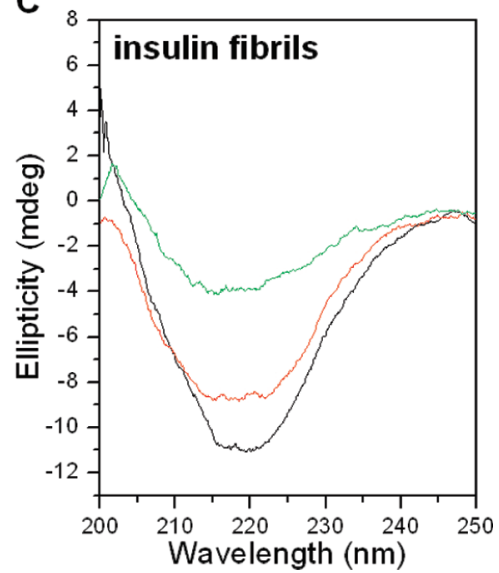

Figure 2. $C D$ spectra of $A \beta 40$ fibrils (A), huPrP fibrils (B), and insulin fibrils $(\mathbf{C})$ before and after digestion by nattokinase at $40^{\circ} \mathrm{C}, \mathrm{pH}$ 7. The spectrum immediately after enzyme addition is shown by the black line. The spectra of samples digested for 1 or $48 \mathrm{~h}$ are shown by the red or green lines, respectively.

A

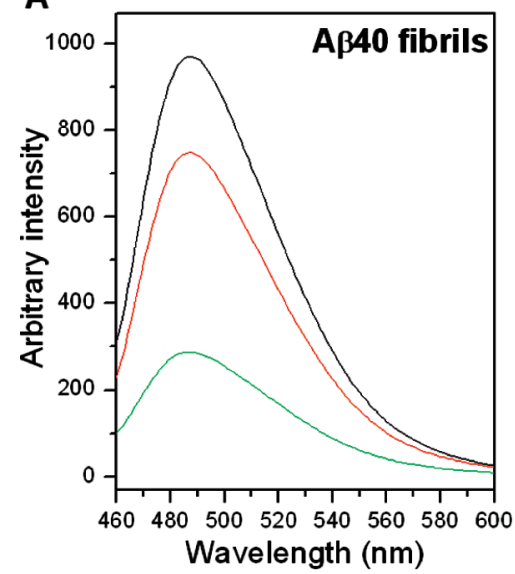

B

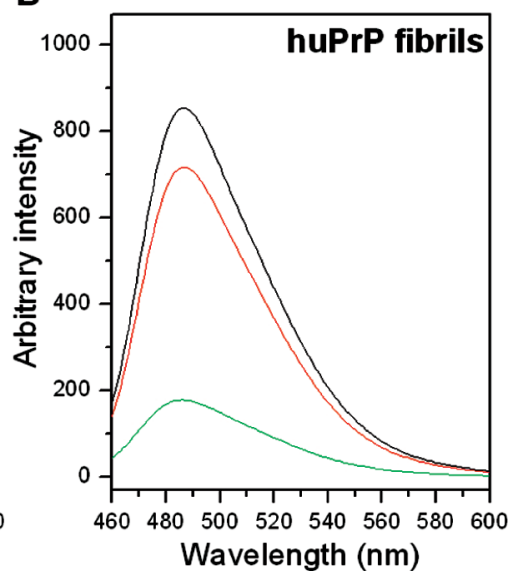

C

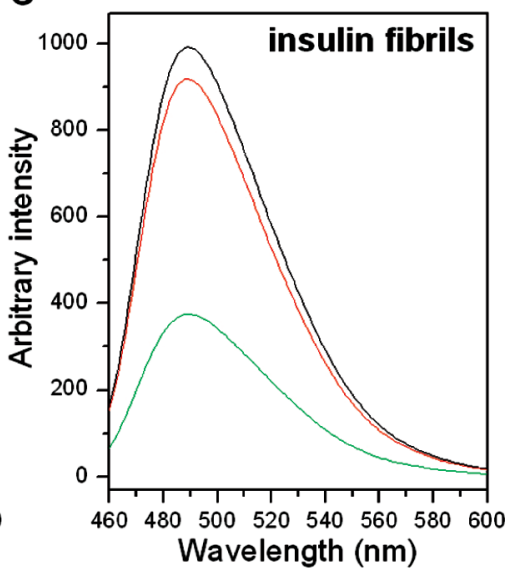

Figure 3. Fluorescence emission spectra of $\mathrm{A} \beta 40$ fibrils (A), huPrP fibrils (B), and insulin fibrils (C) before and after digestion by nattokinase at $40{ }^{\circ} \mathrm{C}$, $\mathrm{pH}$ 7, using ThT binding assay. The spectrum immediately after enzyme addition is shown by the black line. The spectra of samples digested for 1 or $48 \mathrm{~h}$ are shown by the red or green lines, respectively.

temperature and suspended in $50 \mathrm{mM}$ phosphate buffer containing $150 \mathrm{mM} \mathrm{NaCl}, \mathrm{pH} 7$. In order to obtain more homogeneous fibrils, the fibril solutions were incubated in an ultrasonic bath for $10 \mathrm{~min}$ before use. For the enzymatic reaction, $1 \mu \mathrm{L}$ of nattokinase solution was mixed with $179 \mu \mathrm{L}$ of each kind of fibril solution (final nattokinase concentration: $0.27 \mu \mathrm{M}$ ) and the mixture incubated at $40{ }^{\circ} \mathrm{C}$ for $1 \mathrm{~h}$, then fibril digestion was examined by $\mathrm{CD}$ spectroscopy and the ThT binding assay.

Effects of Temperature and pH on the Amyloid-Degrading Activity of Nattokinase. In this experiment, only insulin fibrils were used as the substrate for the enzymatic reaction, as a larger amount of fibrils was needed (insulin is available commercially and fibril formation takes only 2 days). The effect of temperature on nattokinase activity was measured by digestion at various temperatures from 30 to $60{ }^{\circ} \mathrm{C}$ at $\mathrm{pH} 7$, degradation being monitored using the ThT binding assay. To examine the effect of $\mathrm{pH}$ on nattokinase activity, insulin fibrils were suspended in the following buffers: $50 \mathrm{mM} \mathrm{NaOAc}$ and $150 \mathrm{mM} \mathrm{NaCl}(\mathrm{pH}$ 5), $50 \mathrm{mM}$ phosphate and $150 \mathrm{mM} \mathrm{NaCl}$ (pH 6 and 7), $50 \mathrm{mM}$ Tris- $\mathrm{HCl}$ and $150 \mathrm{mM} \mathrm{NaCl}$ (pH 8 and 9), and $50 \mathrm{mM}$ glycine$\mathrm{NaOH}$ and $150 \mathrm{mM} \mathrm{NaCl}(\mathrm{pH} \mathrm{10})$. The reaction was carried out at $40{ }^{\circ} \mathrm{C}$. Nattokinase activity was measured by $\mathrm{CD}$ spectroscopy, as the ThT binding assay is $\mathrm{pH}$-sensitive. The nattokinase concentration used was $0.27 \mu \mathrm{M}$.
Comparison of the A $\boldsymbol{\beta}$ Fibril-Degrading Activity of Different Proteases. The enzymatic reaction was carried out at $37{ }^{\circ} \mathrm{C}$ and $\mathrm{pH} 7$ for $1 \mathrm{~h}$ using nattokinase, proteinase $\mathrm{K}$, subtilisin Carlsberg, trypsin, or plasmin. The reaction mixture comprised $1 \mu \mathrm{L}$ of protease stock $(49 \mu \mathrm{M})$ and $179 \mu \mathrm{L}$ of $\mathrm{A} \beta$ fibril solution (final protease concentration: $0.27 \mu \mathrm{M}$ ), and $30 \mu \mathrm{L}$ of the mixture was removed every $15 \mathrm{~min}$ for testing in the ThT binding assay.

Measurement of Rate of $\mathbf{A} \boldsymbol{\beta}$ Fibril Degradation by Nattokinase. The $\mathrm{A} \beta$ peptide concentration in the fibril form was determined by subtracting the nonaggregated $\mathrm{A} \beta$ peptide concentration in the supernatant fraction after centrifugation from the overall $\mathrm{A} \beta$ concentration. The fibrils were suspended in $50 \mathrm{mM}$ phosphate buffer containing $150 \mathrm{mM} \mathrm{NaCl}$, pH 7.4. Nattokinase was added into the fibril solution at different enzyme concentrations and the mixture was incubated at $37{ }^{\circ} \mathrm{C}$. After different incubation times, the amount of remaining fibril was measured by the ThT binding assay. The rate of fibril degradation was calculated from the time course of fibril degradation.

\section{RESULTS}

Degradation of Amyloid Fibrils by Nattokinase. Nattokinase was purified from liquid culture by gel filtration chromatography. Fractions containing nattokinase were identified using 


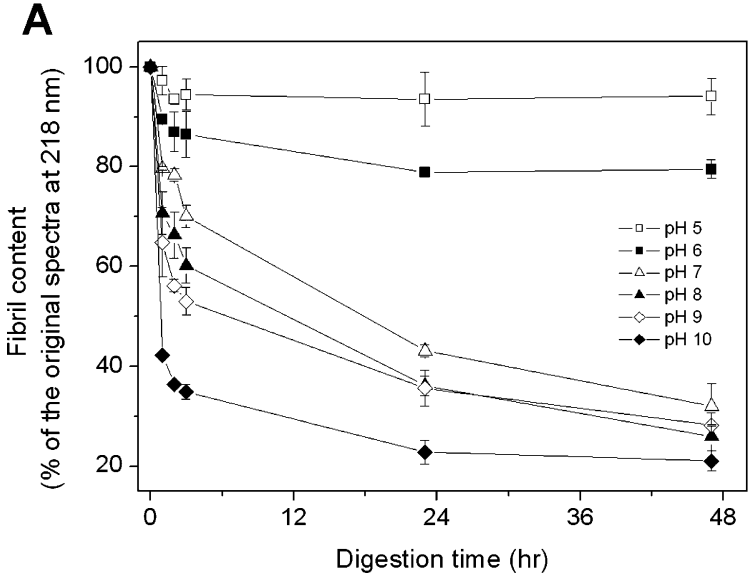

B

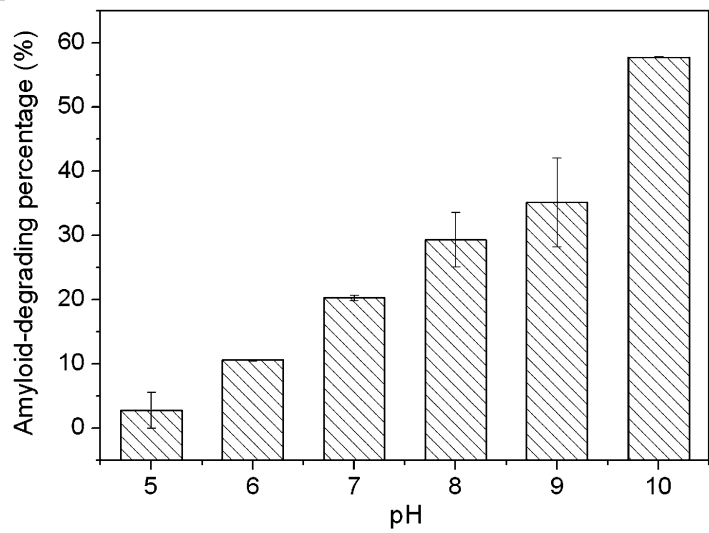

Figure 4. Degradation of insulin fibrils by nattokinase at different $\mathrm{pHs}$. The digestion was carried out at $40^{\circ} \mathrm{C}$ and monitored by $\mathrm{CD}$ spectroscopy. (A) Time-course of degradation monitored by measuring the remaining amyloid fibrils. (B) Percentage amyloid degradation at different $\mathrm{pHs}$ calculated using the data for one hour of digestion. $100 \%$ was defined as the CD ellipticity at $218 \mathrm{~nm}$ of the sample before treatment. The values are the mean \pm SEM for the results of two experiments.

the activity assay, then were tested for the presence of a 27.7 $\mathrm{kDa}$ band on SDS-PAGE. The band was characterized by $\mathrm{N}$-terminal sequence analysis. Those fractions showing a pure protein were pooled and lyophilized (Figure 1).

To determine whether nattokinase has amyloid-degrading activity, $\mathrm{A} \beta 40$ fibrils formed from synthetic $\mathrm{A} \beta 40$ peptide, huPrP fibrils formed from synthetic human prion peptide (containing human prion protein amino acids 108-144 with valine at residue 129), and insulin fibrils formed from purified bovine insulin were used. At $40{ }^{\circ} \mathrm{C}$ and $\mathrm{pH} 7$, nattokinase degraded all three fibrils, as shown by the decrease in the amplitude of the negative ellipticity at $218 \mathrm{~nm}$ in the CD spectra after digestion, indicating loss of $\beta$-sheet structure (Figure 2). Similar results were obtained using the ThT binding assay, in which the decrease in ThT fluorescence intensity at $487 \mathrm{~nm}$ indicated loss of amyloid structure after nattokinase digestion (Figure 3). These results demonstrated that nattokinase was able to degrade all three different amyloid fibrils.

Optimization of Amyloid Digestion by Nattokinase. The fibrinolytic activity of nattokinase is known to be stable at neutral and alkaline $\mathrm{pH}(7-12)$, but labile below $\mathrm{pH} 5$ (3). To examine the effect of $\mathrm{pH}$ on the amyloid-degrading activity of nattokinase, we carried out proteolytic digestion of insulin fibrils over a broad range of $\mathrm{pH}$ values $\left(\mathrm{pH} \mathrm{5-10)}\right.$ at $40^{\circ} \mathrm{C}$. As shown in Figure 4, the activity increased gradually with increasing $\mathrm{pH}$, maximal activity being seen at $\mathrm{pH} 10$ in the range tested. At $\mathrm{pH}$, nattokinase did not show any activity.

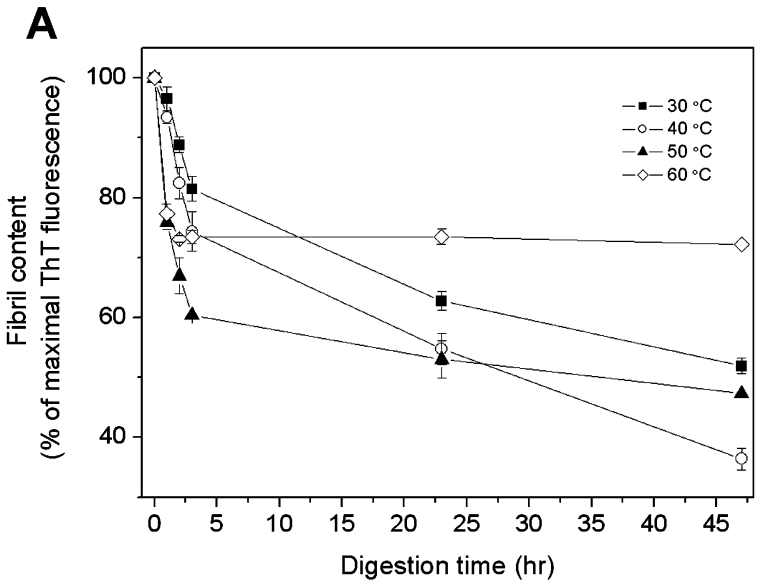

B

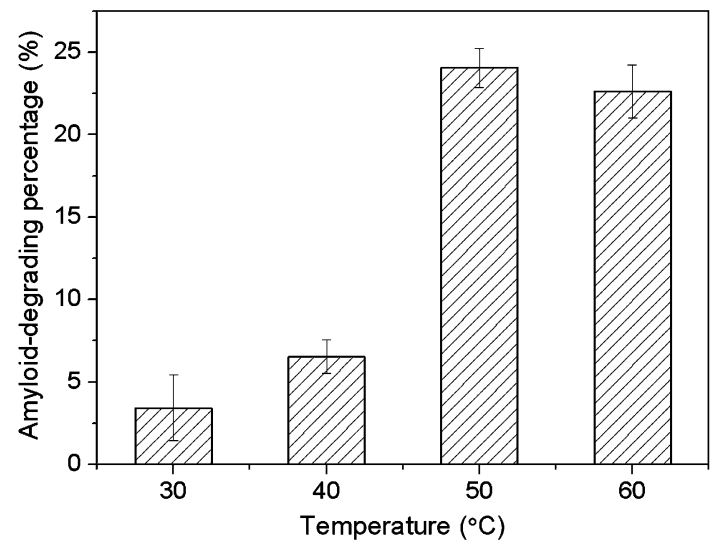

Figure 5. Degradation of insulin fibrils by nattokinase at different temperatures between 30 and $60{ }^{\circ} \mathrm{C}$. The digestion was carried out in phosphate buffer, $\mathrm{pH} 7$, and monitored using the ThT binding assay. (A) Time-course of degradation monitored by measuring the remaining amyloid fibrils. (B) Percentage amyloid degradation at different temperatures calculated using the data for one hour of digestion. $100 \%$ was defined as the fluorescence intensity at $487 \mathrm{~nm}$ of the sample before treatment. The values are the mean \pm SEM for the results of two experiments.

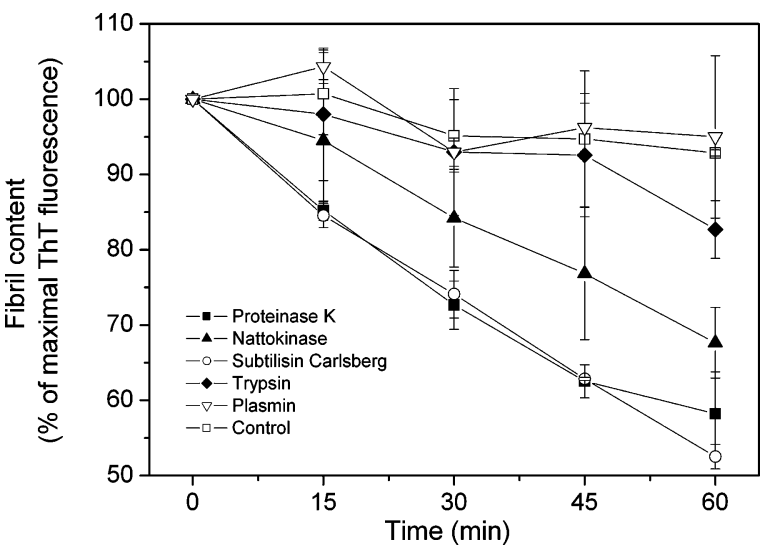

Figure 6. Comparison of $\mathrm{A} \beta 40$ fibril degradation by proteinase $\mathrm{K}$, nattokinase, subtilisin Carlsberg, trypsin, and plasmin. The digestion was carried out at $37^{\circ} \mathrm{C}$ and $\mathrm{pH} 7$ and monitored by the ThT binding assay every $15 \mathrm{~min} .100 \%$ was defined as the fluorescence intensity at $487 \mathrm{~nm}$ of the control before incubation.

In addition, it has been reported that the fibrinolytic activity of nattokinase is gradually lost above $60{ }^{\circ} \mathrm{C}(3)$. We therefore tested the amyloid-degrading ability of nattokinase at different temperatures and $\mathrm{pH}$ 7. As shown in Figure 5, at $60^{\circ} \mathrm{C}$, insulin fibrils were degraded rapidly in the first few minutes, but then 


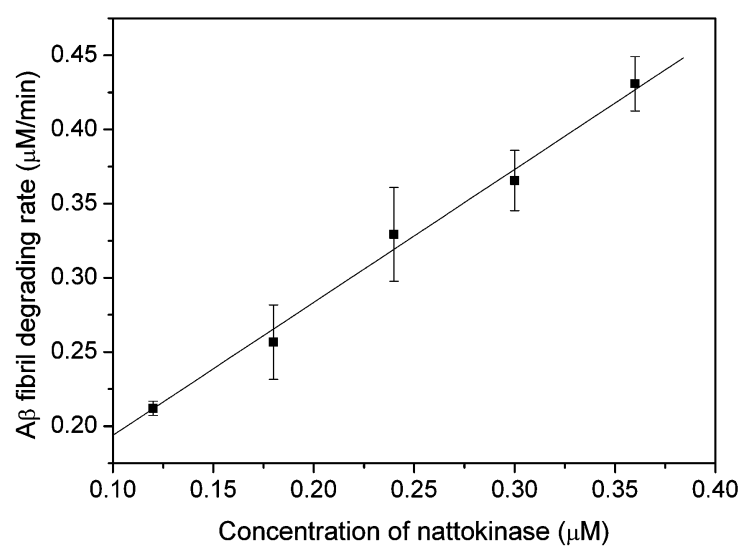

Figure 7. Nattokinase concentration dependence of $\mathrm{A} \beta$ fibril degradation. $\mathrm{A} \beta$ fibril $(44 \mu \mathrm{M})$ was incubated with nattokinase (final enzyme concentration of $0.12,0.18,0.24,0.30$, or $0.36 \mu \mathrm{M})$ at $37^{\circ} \mathrm{C}$ in phosphate buffer, $\mathrm{pH}$ 7.4. The values are the mean \pm SEM for the results of two separate experiments.

digestion stopped, probably due to the inactivation or selfdigestion of nattokinase. At $50{ }^{\circ} \mathrm{C}$, rapid initial digestion was seen, followed by slow digestion, while, at $40{ }^{\circ} \mathrm{C}$, the initial release was less rapid, but digestion continued and was more complete than in the other cases. The percentage of amyloid degradation measured at $40{ }^{\circ} \mathrm{C}$ and $\mathrm{pH} 7$ in the ThT binding assay (Figure 5B) is lower than that measured by $\mathrm{CD}$ spectroscopy under the same condition (Figure 4B). We noted that ThT fluorescence intensity was higher in the insulin fibrils incubated at $40{ }^{\circ} \mathrm{C}$ (data not shown). Since the maximal fluorescence intensity was measured before incubation, these inconsistent data might result from the underestimation of the maximal fluorescence intensity at $40{ }^{\circ} \mathrm{C}$.

Comparison of Nattokinase with Other Proteases. Nattokinase and several other serine proteases were tested for their ability to digest $\mathrm{A} \beta$ fibrils at $37{ }^{\circ} \mathrm{C}$ and $\mathrm{pH}$ 7. The proteases used were proteinase $\mathrm{K}$ (a keratinolytic enzyme and subtilisinlike serine protease used in research on prion diseases), subtilisin Carlsberg, trypsin, and plasmin (a fibrinolytic serine protease). The same protease concentration $(0.27 \mu \mathrm{M})$ was used.

As shown in Figure 6, at $37^{\circ} \mathrm{C}$ and $\mathrm{pH} 7$, proteinase $\mathrm{K}$ and subtilisin Carlsberg degraded $\mathrm{A} \beta$ fibrils at the highest rates. The hydrolysis rate was slower for nattokinase and much slower for trypsin, while plasmin was ineffective. Although the digestion was not performed at the optimal temperatures for proteinase $\mathrm{K}$, subtilisin Carlsberg, or nattokinase in order to mimic body temperature, the amyloid-degrading activities of these proteases were still much greater than those of trypsin and plasmin. Tucker et al. (23) have shown that plasmin can degrade $\mathrm{A} \beta$ monomer and that it can also degrade aggregated $\mathrm{A} \beta$, but the rate $\left(0.003 \mathrm{~s}^{-1}\right)$ is 20 times lower than that for degrading aggregated fibrin $\left(0.064 \mathrm{~s}^{-1}\right)$ and 160 times lower than that for degrading $\mathrm{A} \beta$ monomer $\left(0.48 \mathrm{~s}^{-1}\right)$. In our study, under the same reaction conditions, nattokinase was more efficient than plasmin in cleaving amyloid. Here, the rate of $\mathrm{A} \beta$ fibril degradation by nattokinase was $0.015 \mathrm{~s}^{-1}$ at $37{ }^{\circ} \mathrm{C}$ and $\mathrm{pH} 7.4$ (Figure 7).

\section{DISCUSSION}

In this study, we used three kinds of in vitro prepared amyloid fibrils, A $\beta 40$ amyloid fibrils, insulin amyloid fibrils, and huPrP (consisting prion sequence 108-144) amyloid fibrils, to test the amyloid-degrading ability of nattokinase. $\mathrm{A} \beta 40$ and huPrP peptide have a random coil structure when first dissolved in a buffer with a physiological salt concentration, but, after a few days, undergo a coil-to- $\beta$ structure conversion. The native structure of insulin contains many $\alpha$-helices, but an $\alpha$-to- $\beta$ structural conversion occurs when it is dissolved at acidic conditions and heated at $60{ }^{\circ} \mathrm{C}$. The structural conversion can be confirmed by the appearance of negative ellipticity at 218 $\mathrm{nm}$ in the $\mathrm{CD}$ spectrum, fibril morphology under electron microscopy, and fluorescence emission at $487 \mathrm{~nm}$ in the ThT binding assay. The characteristic cross- $\beta$ structure can be monitored by CD spectroscopy. The ThT binding assay is the most sensitive and widely used method for the detection and quantification of amyloid fibrils. It has been proposed that ThT binds with its long axis parallel to the axis of the amyloid fibrils (24) and that the side chains of the amino acid residues restrict the rotation of ThT, so the fluorescence quantum yield of ThT increases (21). After treatment of the three different amyloid fibrils with nattokinase, the amyloid signal was decreased (Figures 1 and 2), indicating the general amyloid-degrading ability of nattokinase.

This amyloid-degrading ability of nattokinase suggests that it may be useful in the treatment of amyloid-related diseases. The feather-degrading enzyme keratinase (Versazyme), produced by Bacillus licheniformis, can degrade preheated prion (25) and is useful for inactivating prion in meat and bone meal (26) and for decontaminating medical instruments (27), but cannot be taken orally. Many proteins and peptides, such as immunoglobin light chain, transthyretin, $\beta 2$-microglobulin, serum amyloid A protein, $\mathrm{A} \beta$ peptides, and insulin, can form amyloid deposits in the body (28). A $\beta$ peptides can move from the brain into the blood with the aid of low density lipoprotein receptor-related protein and p-glycoprotein (29). In addition, prion disease can be transmitted through blood transfusion (30), suggesting the existence of prion in the blood. Amyloid fibrils are insoluble and not easily digested by proteases. The discovery of an enzyme which can be safely taken orally and can degrade amyloid fibrils could be very useful in the therapy of amyloidrelated diseases. Nattokinase not only dissolved blood clots (9) but also degraded amyloid fibrils. Our amyloid-degrading studies demonstrated that it is active at neutral $\mathrm{pH}$ and body temperature. Previous results in rats, dogs, and humans have suggested that nattokinase can enter the circulation when taken orally $(11,12)$, so it has the potential to clear amyloid deposits in various parts of the body. Moreover, prion diseases can be transmitted by the use of contaminated surgical instruments. Nattokinase can tolerate a temperature of $50{ }^{\circ} \mathrm{C}$ and functions even better under basic conditions, such as $\mathrm{pH} 10$, suggesting that it might be useful in instrument decontamination.

Further animal studies are needed in order to evaluate the therapeutic potential of nattokinase. Various amyloid fibrils can be prepared in vitro and injected into mice. Nattokinase can be given by directly feeding the mice with natto or nattokinase or by injecting nattokinase solution into the body. The amyloiddegrading ability can be tested after an incubation period by detecting the remaining amyloid. Moreover, since natto has been ingested by humans for a long time, it would be worthwhile to carry out an epidemiological study on the rate of occurrence of various amyloid-related diseases in a population regularly consuming natto.

\section{ABBREVIATIONS USED}

huPrP, human prion peptide (sequence108-144 with Val at residue 129); $\mathrm{A} \beta 40$, amyloid $\beta$ peptide (residues 1 to 40 ). 


\section{LITERATURE CITED}

(1) Ueda, S. Industrial applications of B. subtilis: utilization of soybean as natto, a traditional Japanese food. In Bacillus subtilis: molecular biology and industrial applications; Maruo, B., Yoshikawa, H., Eds.; Elsevier Science B. V.: Amsterdam, the Netherlands, 1989; pp 143-161.

(2) Peng, Y.; Yang, X.; Zhang, Y. Microbial fibrinolytic enzymes: an overview of source, production, properties, and thrombolytic activity in vivo. Appl. Microbiol. Biotechnol. 2005, 69, 126-132.

(3) Sumi, H.; Hamada, H.; Tsushima, H.; Mihara, H.; Muraki, H. A novel fibrinolytic enzyme (nattokinase) in the vegetable cheese Natto; a typical and popular soybean food in the Japanese diet. Experientia 1987, 43, 1110-1111.

(4) Kamata, H.; Yamagata, Y.; Nakamura, T.; Nakajima, T.; Oda, K.; Murao, S.; Ichishima, E. Characterization of the complex between $\alpha 2$-macroglobulin and a serine proteinase from Bacillus natto. Agri. Biol. Chem. 1989, 53, 2695-2702.

(5) Fujita, M.; Nomura, K.; Hong, K.; Ito, Y.; Asada, A.; Nishimuro, S. Purification and characterization of a strong fibrinolytic enzyme (nattokinase) in the vegetable cheese natto, a popular soybean fermented food in Japan. Biochem. Biophys. Res. Commun. 1993, 197, 1340-1347.

(6) Nakamura, T.; Yamagata, Y.; Ichishima, E. Nucleotide sequence of the subtilisin NAT gene, aprN, of Bacillus subtilis (natto) Biosci., Biotechnol., Biochem. 1992, 56, 1869-1871.

(7) Fujita, M.; Hong, K.; Ito, Y.; Fujii, R.; Kariya, K.; Nishimuro, S. Thrombolytic effect of nattokinase on a chemically induced thrombosis model in rat. Biol. Pharm. Bull. 1995, 18, 1387-1391.

(8) Urano, T.; Ihara, H.; Umemura, K.; Suzuki, Y.; Oike, M.; Akita, S.; Tsukamoto, Y.; Suzuki, I.; Takada, A. The profibrinolytic enzyme subtilisin NAT purified from Bacillus subtilis cleaves and inactivates plasminogen activator inhibitor type 1. J. Biol. Chem. 2001, 276, 24690-24696.

(9) Chang, C. T.; Fan, M. H.; Kuo, F. C.; Sung, H. Y. Potent fibrinolytic enzyme from a mutant of Bacillus subtilis IMR-NK1. J. Agric. Food Chem. 2000, 48, 3210-3216.

(10) Fujita, M.; Hong, K.; Ito, Y.; Misawa, S.; Takeuchi, N.; Kariya, K.; Nishimuro, S. Transport of nattokinase across the rat intestinal tract. Biol. Pharm. Bull. 1995, 18, 1194-1196.

(11) Sumi, H.; Hamada, H.; Nakanishi, K.; Hiratani, H. Enhancement of the fibrinolytic activity in plasma by oral administration of nattokinase. Acta Haematol. 1990, 84, 139-143.

(12) Suzuki, Y.; Kondo, K.; Matsumoto, Y.; Zhao, B. Q.; Otsuguro, K.; Maeda, T.; Tsukamoto, Y.; Urano, T.; Umemura, K. Dietary supplementation of fermented soybean, natto, suppresses intimal thickening and modulates the lysis of mural thrombi after endothelial injury in rat femoral artery. Life Sci. 2003, 73, 12891298.

(13) Banerjee, A.; Chisti, Y.; Banerjee, U. C. Streptokinase - a clinically useful thrombolytic agent. Biotechnol. Adv. 2004, 22, 287-307.

(14) Uversky, V. N.; Fink, A. L. Conformational constraints for amyloid fibrillation: the importance of being unfolded. Biochim. Biophys. Acta 2004, 1698, 131-153.

(15) Chen, P. Y.; Lin, C. C.; Chang, Y. T.; Lin, S. C.; Chan, S. I. One O-linked sugar can affect the coil-to- $\beta$ structural transition of the prion peptide. Proc. Natl. Acad. Sci. U.S.A. 2002, 99, 12633 12638 .
(16) Zhang, H.; Kaneko, K.; Nguyen, J. T.; Livshits, T. L.; Baldwin, M. A.; Cohen, F. E.; James, T. L.; Prusiner, S. B. Conformational transformations in peptides containing two putative $\alpha$-helices of the prion protein. J. Mol. Biol. 1995, 250, 514-526.

(17) Kuo, L. C.; Cheng, W. Y.; Wu, R. Y.; Huang, C. J.; Lee, K. T. Hydrolysis of black soybean isoflavone glycosides by Bacillus subtilis natto. Appl. Microbiol. Biotechnol. 2006, 73, 314-320.

(18) Kuo, L. C.; Lee, K. T. Cloning, expression, and characterization of two $\beta$-glucosidase from isoflavone glucoside-hydrolyzing Bacillus subtilis natto. J. Agric. Food Chem. 2008, 56, 119-125.

(19) Friberger, P.; Knos, M.; Gustavsson, S.; Aurell, L.; Claeson, G. Methods for determination of plasmin, antiplasmin and plasminogen by means of substrate S-2251. Haemostasis 1978, 7, 138145.

(20) Chang, E. S.; Liao, T. Y.; Lim, T. S.; Fann, W.; Chen, R. P. A new amyloid-like $\beta$-aggregate with most of the amyloid characteristics except fibril morphology. J. Mol. Biol. 2008, 10.1016/ j.jmb.2008.11.009.

(21) Groenning, M.; Norrman, M.; Flink, J. M.; van de Weert, M.; Bukrinsky, J. T.; Schluckebier, G.; Frokjaer, S. Binding mode of Thioflavin T in insulin amyloid fibrils. J. Struct. Biol. 2007, 159, 483-497.

(22) Nielsen, L.; Khurana, R.; Coats, A.; Frokjaer, S.; Brange, J.; Vyas, S.; Uversky, V. N.; Fink, A. L. Effect of environmental factors on the kinetics of insulin fibril formation: elucidation of the molecular mechanism. Biochemistry 2001, 40, 6036-6046.

(23) Tucker, H. M.; Kihiko, M.; Caldwell, J. N.; Wright, S.; Kawarabayashi, T.; Price, D.; Walker, D.; Scheff, S.; McGillis, J. P.; Rydel, R. E.; Estus, S. The plasmin system is induced by and degrades amyloid-beta aggregates. J. Neurosci. 2000, 20, 39373946.

(24) Krebs, M. R. H.; Bromley, E. H. C.; Donald, A. M. The binding of thioflavin-T to amyloid fibrils: localisation and implications. J. Struct. Biol. 2005, 149, 30-37.

(25) Langeveld, J. P. M.; Wang, J. J.; Van de Wiel, D. F. M.; Shih, G. C.; Garssen, G. J.; Bossers, A.; Shih, J. C. H. Enzymatic degradation of prion protein in brain stem from infected cattle and sheep. J. Infect. Dis. 2003, 188, 1782-1789.

(26) Coll, B. A.; Garcia, R. A.; Marmer, W. N. Diffusion of protease into meat \& bone meal for solubility improvement and potential inactivation of the BSE prion. PLOS ONE 2007, 2, e245.

(27) Gupta, R.; Ramnani, P. Microbial keratinases and their prospective applications: an overview. Appl. Microbiol. Biotechnol. 2006, 70, 21-33.

(28) Chiti, F.; Dobson, C. M. Protein misfolding, functional amyloid, and human disease. Annu. Rev. Biochem. 2006, 75, 333-366.

(29) Wang, Y. J.; Zhou, H. D.; Zhou, X. F. Clearance of amyloidbeta in Alzheimer's disease: progress, problems and perspectives. Drug Discovery Today 2006, 11, 931-938.

(30) Hunter, N.; Foster, J.; Chong, A.; McCutcheon, S.; Parnham, D.; Eaton, S.; MacKenzie, C.; Houston, F. Transmission of prion diseases by blood transfusion. J. Gen. Virol. 2002, 83, 2897-2905.

Received for review October 2, 2008. Revised manuscript received November 23, 2008. Accepted November 23, 2008.

JF803072R 